\title{
Peran Remaja Masjid Dalam Meningkatkan Dakwah
}

\author{
${ }^{1}$ Sony Eko Adisaputro, ${ }^{2}$ Sutamaji, ${ }^{3}$ Muhammad Amrillah \\ IAI Pangeran Diponegoro Nganjuk \\ ${ }^{1}$ sonyeko@iaipd-nganjuk.ac.id, ${ }^{2}$ sutamaji@iaipd-nganjuk.ac.id, \\ 3amrillah084@gmail.com
}

\begin{abstract}
ABSTRAK
Penelitian ini berjudul "Peran Remaja Masjid Baitul Mustofa Qauman Dalam Meningkatkan Dakwah" ,merupakan penelitian yang meneliti tentang Perjuangan REMAS di dalam memajukan Dakwah di Kab. Nganjuk. Penelitian ini berusaha mengetahui : 1) Bagaimana Peran remaja masjid Baitul Mustofa Qouman dalam kemajuan dakwah? Metode Penelitian : Berdasarkan Sumber datanya penelitian ini termasuk penelitian lapangan, dan ditinjau dari segi sifat-sifat data termasuk dalam penelitian kualitatif, berdasarkan pembahasannya termasuk penelitian deskriptif dengan menggunakan pendekatan deskriptif kualitatif. Data dikumpulkan dengan metode observasi, wawancara dan dokumentasi. Analisa data dilakukan mulai dari reduksi data, penyajian data dan penarikan kesimpulan. Hasil penelitian : Menunjukkan bahwa keberadaan remaja masjid memiliki fungsi dan peranan yang sangat penting di dalam komunitas tersendiri. Dalam menjalankan peranannya, aktivitas kegiatan yang dilakukan oleh remaja masjid yang ada di Desa Plosoharjo tidak hanya fokus pada bidang keremajaan, melainkan bidang kemasjidan untuk memperluas jangkauan aktivitas dan pelayanannya dalam mencapai kemakmuran masjid yang dicita-citakan. Adanya Remas dalam memakmurkan masjid yaitu dengan cara Melakukan Shalat berjamaah di Masjid, dan Melakukan Peringatan hari-haribesar di Masjid, Dampak adanya Remas ini dari pengurus dan anggota aktif sendiri juga menunjukkan kepada masyarakat kalau organisasi mereka ini adalah organisasi yang positif. Sampai saat ini pun masyarakat juga sangat antusias dalam mendukung organisasi remaja masjid ini, dan ini pun juga berdampak positif bagi anggota yaitu, menjadikan banyak nya anggota baru..
\end{abstract}

\section{Kata Kunci: Peran remaja masjid, Kemajuan Dakwah}

\section{PENDAHULUAN}

Masjid pada awalnya merupakan tempat pusat segala kegiatan, bukan saja sebagai pusat ibadah khusus, seperti shalat dan i'tikaf. Akan tetapi, masjid merupakan pusat kebudayaan dan muamalat. Masjid merupakan tempat dimana lahir kebudayaan Islam yang demikian kaya dan berkah. Kejayaan umat Islam yang telah tertulis di dalam lembaran-lembaran sejarah peradaban Islam tidak bisa dilepaskan dari proses pendidikan Islam yang dilakukan di masjid.

Masjid memiliki fungsi edukasi diantaranya adalah berfungsi untuk pengembangan nilai-nilai humanis dan kesejahteraan umum. Fungsi tersebut bisa disebut sebagai fungsi edukasi. Fungsi edukasi ini seringkali terlewatkan dari perhatian umat meski tetap disadari bahwa fungsi tersebut penting untuk 
dikembangkan. Mengembangkan fungsi edukasi masjid dimulai dari pemahaman tentang konsep pendidikan Islam secara benar dan tidak dimaknai secara sempit. Pendidikan Islam merupakan pendidikan yang secara komprehensif-integratif mengembangkan potensi manusia baik fisik-material, emosi, dan juga spiritualnya.

Jika berbicara tentang masjid, maka tidak terlepas dengan peran remaja masjid. Pada masa dahulu, Peran remaja masjid sangatlah penting terutama dalam membentuk generasi islam serta pembentukan karakter.Dakwah yang dilakukan untuk menyebarkan islam di Nusantara sangatlah terencana dan tidak spontanitas. Sehingga berhasil mengubah masyarakat yang dulu mayoritas Hindu menjadi mayoritas Muslim tanpa harus merusak nilai-nilai budaya.

Melalui peran remaja masjid, masjid mampu menjadi wadah pembentukan karakter serta pendidikan karakter bagi masyarakat sekitar khususnya remajaremaja yang dalam dunia nyata pergaulannya kini sangat rawan. Dimana banyak kita jumpai pergaulan para remaja di luar sana yang memprihatinkan dan layak untuk diberikan bimbingan serta arahan-arahan.

Hal itu bisa terjadi karena adanya beberapa faktor seperti tidak adanya upaya yang dilakukan oleh anggota masyarakat sekitar dalam mengembalikan moral dan karakter anak serta peran masyarakat itu sendiri dalam memberikan sentuhan pendidikan karakter.

Remaja masjid merupakan organisasi dakwah Islam anak organisasi (underbouw) takmir masjid, yang mengambil spesialisasi pembinaan remaja muslim melalui masjid. Disimpulkan bahwa yang dimaksud dengan Remaja masjid adalah pekumpulan para remaja dalam suatu organisasi yang diadakan dimasjid dan mempunyai tujuan untuk menumbuhkan akhlak yang baik, budi pekerti luhur dan menjadi teladan bagi remaja lainnya.

Dalam kemajuan dakwah di lingkungan pedesaan tidak cukup hanya dengan mengandalkan kegiatan keagamaan yang sudah menjadi rutinitas dalam suatu wilayah tersebut. Apalagi dengan bertambah canggih dan majunya teknologi dan informasi di era globalisasi seperti zaman ini, dakwah agama juga harus di sebar luaskan serta dikembangkan juga. Dan jika hanya mengandalkan pemuka agama di suatu wilayah saja maka dakwah itu pun tidak akan bisa disampaikan secara maksimal. Selain itu dengan adanya organisasi yang bernama REMAS (Remaja Masjid) ini bisa menjadi suatu wadah untuk mengembangkan bakat-bakat keagamaan di lingkungan tersebut, selain itu REMAS sendiri juga bisa menjadi oraganisasi yang bisa mengembalikan fungsional masjid.

Seperti halnya yang dilakukan remaja masjid Baitul Mustofa Qouman , dalam rangka mengembalikan nilai religius serta pendidikan karakter bagi masyarakat sekitar khususnya anak-anak remaja. Sebagaimana mestinya, remaja masjid berupaya melakukan berbagai macam kegiatan penunjang serta strategi secara rutin kepada masyarakat sekitar, seperti halnya ustadz yang menggandeng beberapa santri atau aktivis masjid yang akan menjadi penerus generasi di desa 
tersebut mengadakan suatu kegiatan yang bisa mengajak para remaja-remaja sekitar untuk mau ikut serta dalam kegiatan keagamaan di desa tersebut. Harapannya adalah melalui berbagai macam kegiatan tersebut akan timbul kesadaran pentingnya menjaga moral serta katrakter dalam diri masing-masing individu. Dari sini lah nanti nya bisa ternilai oleh masayarakat betapa pentingnya peran REMAS ini terhadap kemajuan dakwah.

Remas sebagai wadah pembinaan remaja islam memiliki peran yang sangat penting dalam mewujudkan remaja islam yang beriman, dan bertaqwa kepada Allah SWT.

Menurut Ayub, pembinaan remaja islam dapat dilakukan dengan berbagai cara yaitu:

a. Melakukan bimbingan agama dan moral secara rasional.

b. Melakukan bimbingan, berdiskusi dan bermusayawarah.

c. Menyediakan buku bacaan tentang agama, moral, dan ilmu pengetahuan.

d. Memberikan kesempatan untuk berperan dan bertanggung jawab sebagai orang dewasa melalui wahana organisasi.

e. Memberikan perlindungan terhadap pengaruh negatif dari lingkungan dan media massa.

f. Membimbing dan mengawasi pergaulan muda-mudi.

g. Menyalurkan hobi yang sehat dan bermanfaat.

h. Memberikan kesempatan berolahraga.

i. Memberikan kesempatan berpiknik.

Remas memiliki berbagai kegiatan yang semuanya mengandung unsur pembinaan terhadap remaja dalam membina pengamalan ibadah baik kegiatan yang bersifat pengajian dan kegiatan yang bersifat keagamaan atau kegiatan bersifat sosial.Kegiatan-kegitan pengajian sebagai salah satu kegiatan bersifat keagamaan yang membahas masalah-masalah yang berkaitan denga ibadah, muamalah akhlak dan masalah-masalah remaja. Sehingga diharapkan setelah mengikuti pengajian ini pengetahuan agama remaja akan bertambah dan pengamalan ibadah mereka lebih baik. Kegiatan olah raga dan kesenian dilaksanakan untuk mengetahui bakat dan mengembangkan kreativitas mereka. Dan bertujuan untuk semakin memper erat tali sillaturahmi antar anggota Remas.

Mengadakan Kegiatan peringatan hari besar islam atau PHBI dapat menambahkan semangat mereka untuk rajin ke masjid meneladani perjalanan hidup dan akhlak rasul, mengetahui sejarah islam dan lebih mempererat tali persaudaraan antar sesama muslim. Kegiatan pengajian silaturahmi antar Remas diadakan setiap 1 bulan sekali bertujuan untuk salah satunya yakni evaluasi baik bagi pengurus maupun anggota REMAS, selain itu juga bertujuan untuk menjalin tali siilaturrahim antar remaja masjid dengan Remas yang lain. 
Mengenai kegiatan untuk remaja masjid Baitul Mustofa Qouman ini sangat lah unik, kita ambil dari salah satu narasumber yang telah kita wawancarai. Mulai dari awal pembentukan remaja masjid ini dulu diadakan semacam arisan, dengan harapan semua remaja di desa tersebut bisa terkumpulkan dan mengenal satu sama lain, serta peresmian organisasi REMAJA MASJID disitu ustadz langsung mengundang kepala desa untuk menyetujui serta meresmikan organisasi ini. Setelah itu agenda arisan kita adakan seminggu sekali di tempat yang sama dengan harapan yang masih sama yaitu mengumpulkan dan mengenal kan satu sama lain,disetiap pertemuan itu kita masih baru membahas tentang kegiatan-kegiatan yang akan kita jalani seperti halnya gotong royong membersihkan mushola-mushola yang ada di desa itu dengan cara gilir hari dan mengikuti semua kegiatan keagamaan yang ada di desa itu, misalkan harus ikut serta jika ada rutinan khotmil qur'an di salah satu mushola. Dan kegiatan itu berjalan seterus nya.

Ditengah-tengah perjuangan pembentukan REMAS juga ada yang pro dan kontra. Ada yang merasa terganggu dengan adanya organisasi ini karena merasa terbebani dengan adanya arisan tersebut. Ada juga yang merasa senang dengan adanya organisasi ini masjid jadi kelihatan hidup dan masyarakat pun jadi merasa terbantu dengan adanya oraganisasi REMAS ini karena sudah menjadi niat awal para aktivis masjid atau REMAS ini untuk membantu dan mengajak semua kalangan anak remaja untuk selalu mau belajar kebaikan dan meramaikan masjid dengan berbagai kegiatan keagamaan..

\section{METODE PENELITIAN}

Metode penelitian yang digunakan dalam penelitian ini adalah metode penelitian kualitatif dengan jenis deskriptif. Menurut Moleong penelitian kualitatif adalah penelitian yang bermaksud untuk memahami fenomena tentang apa yang dialami oleh informan penelitian misalnya perilaku, persepsi, minat, motivasi, tindakan, dan lain sebagainya. Oleh karena itu penelitian ini dapat diartikan sebagai metode yang memberikan hasil dari data penelitan dilapangan yang berkenaan dengan interprestasi terhadap data yang dihasilkan sebagai bentuk kebenaran dari berbagai asumsi yang terjadi sebelum dilakukan penelitian.

Jenis penelitian yang digunakan pada penelitian ini adalah jenis penelitian kualitatif deskriptif. Menurut Moleong penelitian deskriptif adalah peneliti yang mengeksplorasi serta mengumpulkan data berupa kata-kata, gambar, dan bukan angka-angka atau dapat diartikan bahwa peneltian deskriptif adalah suatu bentuk penelitian yang ditujukan untuk mendeskripsikan atau menggambarkan fenomenafenomena yang ada, baik fenomena alamiah maupun rekayasa manusia . Sehingga dari hasil penelitian ini akan berupa kata-kata yang tertulis atau lisan dari perilaku yang diamati. Adapun tujuan penelitian deskripti adalah untuk membuat pencandraan secara sistematis, faktual dan akurat mengenai fakta dan sifat populasi atau daerah tertentu. Penelitian ini digunakan untuk mengetahui manajemen media 
online facebook dalam meningkatkan prilaku moral pada anggota lembaga Badan Permusyawaratan Desa (BPD) Jatigreges Kecamatan Pace Kabupaten Nganjuk.

Penelitian tentang manajemen Media Online Facebook Dalam Meningkatkan Moral Pada Anggota Lembaga Badan Permusyawaratan Desa (BPD) Desa Jatigreges Kecamatan Pace Kabupaten Nganjuk. Oleh sebab itu untuk dapat menganalisis dan mengetahui manajeman dalam penelitian ini maka peneliti menggunakan pendekatan metodologi studi kasus. Menurut Krisyantoro Studi kasus dapat diartikan sebagai metode riset yang menggunakan sumber data yang dapat digunakan untuk meneliti, menguraikan dan menjelasakan secara komprehensif sebagai aspek individu. Penggunaan studi kasus ini merupakan pertimbangan dari beberapa hal unik untuk menggali informasi dari organisasi atau lembaga .

Alasan yang mendasar peneliti menggunanakan metode studi kasus, karena peneliti dapat terfokus pada satu fenomena, yaitu begaimana manajemen media online facebook dalam meningkatkan perilaku moral pada anggota lembaga BPD baik berupa peningkatan kualitas anggota, komunikasi antar anggota dan emosional anggota satu dengan anggota yang lain.

Peneliti harus hadir dalam tempat penelitian agar dapat mengamati orang yang akan digunakan sebagai sumber data penelitian, tetapi tidak ikut terlibat dalam kegiatan tersebut. Kedudukan peneliti dalam penelitian kualitatif cukup rumit, peneliti merupakan perencana, pelaksana pengumpulan data, analisis, penfsiran data, dan hasilnya akan menjadi laporan hasil penelitiannya. Selain itu, kehadiran peneliti diketahui statusnya oleh Subjek atau informan.

\section{HASIL DAN PEMBAHASAN}

Di dalam organisasi remaja masjid ini, para anggota dan aktivis masjid diharapkan bisa mengembangkan ilmu agama nya, mengembalikan fungsi masjid dan memakmurkan masjid kembali. Karena itu harus ada nya hubungan yang baik antara anggota remaja masjid dengan masyarakat sekitar, karena itu nantinya akan berkesinambungan antara satu sama lain. Dan diharap kan para remaja ini menjadi tombak utama dalam penyaluran dakwah agama nantinya, menjadi pengembang dan menjadi salah satu organisasi yang bernilai tinggi ditengah-tengah masyarakat.

Remaja Masjid merupakan bagian dari generasi muda yang ada di Desa Plosoharjo, yang sadar akan hak dan kewajiban kepada masyarakat, bangsa dan agama sehingga bertekad untuk mendharma bhaktikan segenap potensi yang dimilikinya. Niat suci tersebut kemudian terikat dalam sebuah wadah perjuangan yang terorganisir dengan senantiasa mengedepankan semangat kekeluargaan dalam pembangunan pribadi-pribadi yang tangguh, mandiri, bertanggung jawab dengan tetap menjadikan al-Qur'an dan As sunnah sebagai pedoman hidup.

Memakmurkan masjid merupakan salah satu bentuk taqarrub (upaya mendekatkan diri) kepada Allah yang paling utama. Memakmurkan masjid 
merupakan salah satu bentuk taqarrub (upaya mendekatkan diri) kepada Allah yang paling utama.

Memakmurkan masjid mempunyai arti yang sangat luas, yaitu penyelenggaraan berbagai kegiatan yang bersifat ibadah mahdhah (perbuatan yang sudah ditentukan syarat dan rukunnya) hubungan dengan Allah (hablumminallah), maupun hubungan sesama manusia (hablumminannass) yang bertujuan untuk meningkatkan iman dan takwa, kecerdasan dan kesejahteraan jasmani, rohani, ekonomi maupun sosial. Adapun peran dan fungsi remaja masjid sebagi berikut:

a. Memakmurkan Masjid

Remaja masjid adalah organisasi yang memiliki keterkaitan dengan masjid. Diharapkan anggotanya aktif datang ke masjid, untuk melaksanakan salat berjamaah bersama dengan umat Islam yang lain, karena salat berjamaah adalah merupakan indikator utama dalam memakmurkan masjid. Selain itu, kedatangan mereka ke masjid akan memudahkan pengurus dalam memberikan informasi, melakukan koordinasi dan mengatur strategi organisasi untuk melaksanakan aktivitas pembinaan akhlak santri yang telah dibuat.

b. Kaderisasi Umat

Pengkaderan adalah suatu proses pembentukan kader yang dilakukan sedemikian rupa sehingga diperoleh kader yang siap mengemban amanah organisasi. Pengkaderan anggota remaja masjid dapat dilakukan baik secara langsung maupun tidak langsung. Pengkaderan langsung dapat dilakukan melalui pendidikan dan pelatihan yang terstruktur, secara tidak langsung dapat dilakukan melalui kepengurusan, kepanitiaan dan aktivitas organisasi lainnya. Sebagai wadah generasi muda Islam, remaja masjid berusaha untuk mengkader anggotanya dengan membekali mereka dengan berbagai kemampuan yang memadai, baik kemampuan teknis operasional (technical skill), kemampuan mengatur orang (human skill), maupun dalam menyusun konsep (conseptual skill), sehingga manfaat yang diperoleh dari pengkaderan dapat menjadi kaderkader organisasi remaja masjid yang "siap pakai" yaitu kader-kader yang beriman, profesional, aktivis Islam yang terampil, anggota yang bermotivasi tinggi, memiliki kader yang berpengetahuan dan tingkat intelektualitas yang baik serta menghadirkan calon pemimpin yang memiliki kemauan dan kemampuan dalam meneruskan misi organisasi.

Melakukan pengkaderan terhadap anggota remaja masjid, dapat memperoleh kader yang tangguh dan siap mengemban tugas organisasi khusunya dalam mengemban dakwah Islam.

c. Pembinaan Remaja Muslim

Remaja muslim di sekitar lingkungan masjid merupakan sumber daya manusia (SDM) yang sangat mendukung bagi kegiatan organisasi, sekaligus juga merupakan objek dakwah (madu) yang paling utama. Oleh karena itu, mereka harus dibina secara bertahap dan berkesinambungan, agar mampu 


\section{JKIIs

beriman, berilmu dan beramal saleh dengan baik. Selain itu, juga mendidik mereka untuk berilmu pengetahuan yang luas serta memiliki keterampilan yang dapat diandalkan. Dengan pengajian remaja, mentoring, malam bina iman dan takwa (MABIT), bimbingan membaca dan tafsir al Qu'an, kajian buku, pelatihan (training), ceramah umum, keterampilan berorganisasi dan lain sebagainya.

Remaja muslim merupakan sumber daya manusia yang sangat penting dalam sebuah organisasi maka penting untuk dilakukan pembinaan secara berkesinambungan agar mereka memiliki keterampilan yang dapat diandalkan.

d. Pendukung Kegiatan Takmir Masjid

Sebagai anak organisasi takmir masjid, remaja masjid harus mendukung program dan kegiatan induknya. Dalam pelaksanaan kegiatankegiatan tertentu, seperti salat jum'at, penyelenggaraan kegiatan Ramadan, Idul Fitri dan Idul Adha dan lain sebagainya. Di samping bersifat membantu, kegiatan tersebut juga merupakan aktivitas yang sangat diperlukan dalam bermasyarakat secara nyata. Secara umum, remaja masjid dapat memberi dukungan dalam berbagai kegiatan yang menjadi tanggung jawab takmir masjid, diantaranya:

1) Mempersiapkan sarana salat berjamaah dan salat-salat khusus, seperti salat gerhana matahari, gerhana bulan, minta hujan, Idul Fitri dan Idul Adha.

2) Menyusun jadwal dan menghubungi khatib jum'at, Idul Fitri, dan Idul Adha.

3) Menjadi panitia kegiatan-kegiatan kemasjidan.

4) Melaksanakan pengumpulan dan pembagian zakat.

5) Menjadi pelaksana penggalangan dana.

6) Memberikan masukan yang dipandang perlu kepada takmir masjid dan lain sebagainya.

Uraian di atas dapat ditarik kesimpulan bahwa fungsi remaja masjid bukan hanya memakmurkan masjid tapi juga ikut serta sebagai pendukung kegiatan kegiatan yang dilakukan oleh pengurus masjid. Dakwah dan Sosial Remaja masjid adalah organisai dakwah Islam yang mengambil spesialisasi remaja muslim melalui masjid. Organisasi ini berpartisipasi secara aktif dalam mendakwahkan Islam secara luas, disesuaikan dengan situasi dan kondisi yang melingkupinya. Aktivitas dakwah bil lisan, bil hal, bil qalam dan lain sebagainya dapat diselenggarakan dengan baik oleh pengurus maupun anggotanya.Remaja masjid dalam menyelenggarakan aktivitas tersebut tidak hanya membatasi pada bidang keremajaan saja tetapi juga melaksanakan aktivitas yang menyentuh masyarakat luas, seperti bakti sosial, kebersihan lingkungan, membantu korban bencana alam dan lain-lain, semuanya adalah merupakan contoh dari aktivitas dakwah yang dilakukan oleh remaja masjid dan mereka dapat bekerja sama dengan takmir masjid dalam merealisasikan 
kegiatan kemasyarakatan tersebut. Remaja masjid dalam menjalankan fungsinya bukan hanya berdakwah dengan lisan tetapi mengajak masyarakat dengan cara memberikan contoh yang baik seperti membantu korban bencana, bakti sosial dan lain sebagainnya dan dakwah ini disebut dakwah bil hal (dengan perbuatan). Seperti hadist dibawah ini:

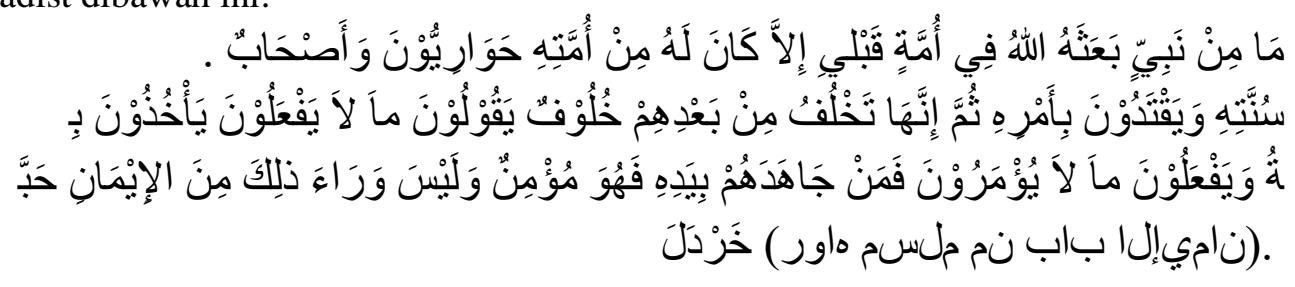

"Tidaklah seorang nabi yang diutus Allah dari umat sebelumku, kecuali dari umatnya terdapat orang-orang hawariyun (para pembela dan pengikut) yang melaksanakan sunnahnya serta melaksanakan perintah-perintahnya. Kemudian, datang generasi setelah mereka; mereka mengatakan sesuatu yang tidak mereka kerjakan dan mereka mengerjakan sesuatu yang tidak diperintahkan. Oleh karena itu, siapa yang berjihad terhadap mereka dengan tangannya, maka ia adalah orang mukmin, siapa yang berjihad melawan mereka dengan lisannya, maka ia adalah orang mukmin. Dan siapa yang berjihad melawan mereka dengan hatinya, maka ia adalah orang mukmin. sedangkan di bawah itu semua tidak ada keimanan meskipun hanya sebesar biji sawi (H. R. Muslim)".

Dan seperti yang sudah dijelaskan di atas, peran remaja masjid Baitul Mustofa Qouman adalah mengembalikan fungsi masjid seperti yang di harapkan oleh kyai, dan masyarakat sekitar yaitu memakmurkan masjid kembali.

\section{SIMPULAN DAN SARAN}

Dengan memperhatikan uraian penelitian, hasil temuan penelitian, dan pembahasan mengenai manajemen media online facebook dalam meningkatkan perilaku moral pada anggota lembaga Badan Permusyawaratan Desa (BPD) desa Jatigreges kecamatan Pace kabupaten Nganjuk, maka penelitian ini dapat penulis simpulkan.

1) Perencanaan postingan positif dan bermanfaat. citra diri sebagai pertahanan pribadi untuk mengelola identitas, pemilihan pesan dan seleksi pertemanan dan mempertimbangkan efek yang akan terjadi. Persiapan diutamakan postingan yang berkualitas agar menjadi sarana terbaik aspirasi dan inspirasi masyarakat.

2) Pelaksanaan dinilai positif karena menghasilkan berbagai informasi yang positif dan dapat dimanfaat oleh masyarakat secara luas. Sehingga pencapaian ini terbilang sukses untuk mempertahankan perilaku moral baik dalam dunia kerja maupun dunia maya anggota.

3) Pengawasan kurang baik sehingga masih ada hal-hal yang sedikit menyimpang dalam etika penggunaan media online facebook. Evaluasi dilakukan lewat chat 


\section{JKis sompram

personal oleh pimpinan anggota BPD, memperingatkan untuk citra pribadi dan lembaga BPD khususnya.

\section{DAFTAR PUSTAKA}

Abdul Kadir Sayid Abd. Rauf, Dirasah Fid Dakwah Al Islamiyah Cet. I; Kairoh: Dar, El Tiba'ahal al-Mahmadiyah, 1987

Ahmad Muhsin Kamaludiningrat, Meningkatkan Peran dan Fungsi Masjid dalam Dakwah dan Pembinaan Masyarakat Madani Beriman dan Bertaqwa Jogjakarta: Jurnal Ulama, 2010

Ahmad Tanzeh dan Suyitno, Dasar-dasar Penelitian, Elkaf, Surabaya: 2006,

Ahmad Warson al-Munawwir, al-Munawwir Cet. XIV; Pustaka Progresif, Jakarta: 1997

Arif Furchan, Pengantar Penelitian dalam Pendidikan, Pustaka Pelajar, Yogyakarta: 2005,

Burhan Bunging, Penelitian kualitatif Edisi Kedua; Kencana, Jakarta: 2007

Deddy Mulyana, Metodologi Penelitian Kualitatif, PT Rosda Karya, Bandung: 2006,

Ghazali Darussalam, Dinamika Ilmu Dakwah Islamiyah Cet. I; Nur Niaga SDN. BHD, Malaysia: 1996

H. M. S. Nasaruddin Latief, Teori dan Praktek Dakwah Islamiah Firma Dara, tt, Jakarta: PT

Hasanuddin, Hukum Dakwah Cet. I; Pedoman Ilmu Jaya, Jakarta: 1996

Hurima, dkk. dalam laporan penelitian Pelaksanaan Kegiatan Remaja masjid Al Mustaqim Kelurahan Sail Kecamatan Tenayan Raya, Universitas Riau, pdf

Kementerian Agama RI, Al-Qur'an dan Terjemahnya PT Tiga Serangkai Pustaka Mandiri, Solo: 2014

Lexy. J. Moleong, Metodologi Penelitian kualitatif Rosdakarya, Bandung: 2001

M. Arifin, Ilmu Pendidikan Islam Cet.I; Bumi Aksara, Jakarta: 1991

Majma' al-Lughah al-'Arabiyah, 1972: 286. 
Peran Remaja Masjid Dalam Meningkatkan Dakwah 